\title{
Review of Indosphere Revival: Strategies to meet Sinic Challenge by Pulind Samant
}

Reseña de Indosphere Revival: Strategies to meet Sinic Challenge de Pulind Samant

\section{Ketut Ardhana}

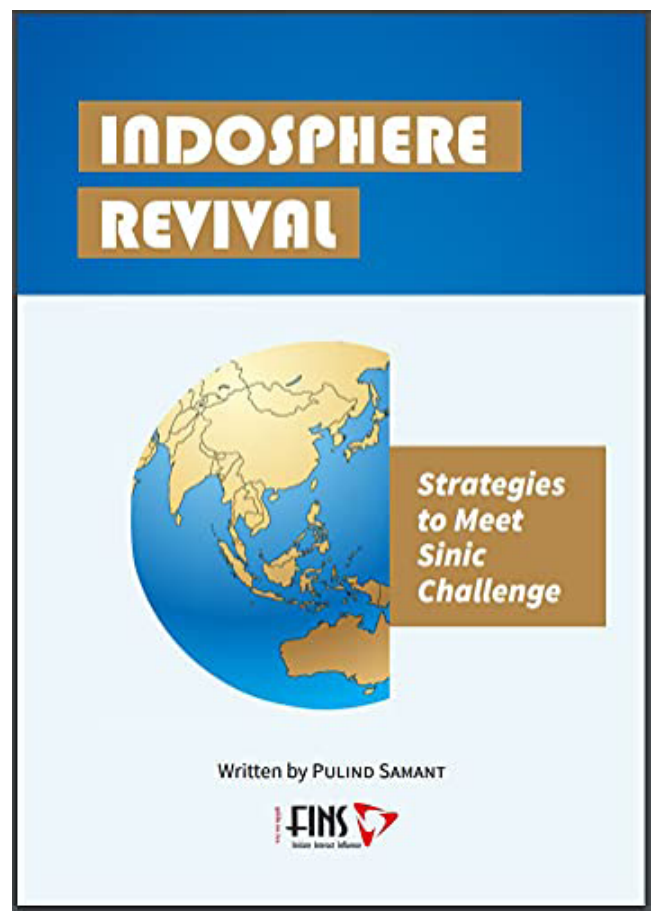

Pulind Samant

Indosphere Revival: Strategies to meet Sinic Challenge.

Forum for Integrated National Security, 2020

\section{Introduction}

There are very limited sources, particularly in the context of the academic references that are available regarding the Indosphere and Sinosphere in the Southeast Asia region. The presence of Indianization or Hinduization and Chinaization have become major topics in the context of Southeast Asian Studies. The study of the Indosphere would provide very valuable information that could provide further knowledge of today's India as well as ancient India. Those ancient relationships had shared a general observation that colonies preserved their customs, beliefs, and language, many archaic traits that dated back to the origin of colonization and fell into disuse in the mother country. The Indosphere had not been any exception to that rule, and the study of ancient India viewed from the East has scarcely begun, seems to provide rich results. It can be understood that neither India and China never successfully colonized Southeast Asia in terms of politics, though the Chinese successfully played a major role in economic and trade activities in the Indonesian archipelago for such a long time. This is true of Indonesian history in particular and in the Southeast Asian history in general. Though, in fact, certain military and political actions such as the role of the King Kubhilai Kan from China, coming to Java during the Singasari Kingdom in the $13^{\text {th }}$ century were significant.

\section{CONFLICT OF INTEREST}

No potential conflict of interest is reported by the author.

\section{FUNDING}

No financial assistance from parties outside this article.

ACKNOWLEDGMENTS

N/A

NOTE

$\mathrm{N} / \mathrm{A}$
ENTIDAD EDITORA 
The presence of a book written by Pulind Samant titled, Indosphere Revival: Strategies to meet the Sinic Challenge can be considered as an outstanding book. It is important to look at the biography of Pullind Samant who had been a Human Resource Management professional for 27 years till year 2017. Since then, he has been into research and related pursuits in the subjects of international relations, specializing in the India-centric geopolitical and geostrategic dimensions of the Southeast Asia region. He is a Ph.D. student and studies in the VPM center for international studies (Mumbai), an affiliated center of the University of Mumbai.

His book, it is expected to give a comprehensive understanding about the dynamics of the region due to the intensive Indian and Chinese cultural influences not only in the past, but also in the present and the future. Pullind Samant's book consists of several parts including Indonesia's Bharata for India's Rama, the Malaysian Mismatch, Thailand-Shyama of Ayodhya, Vietnam- the Vet and the Cham, Kamboja and Leave Pradesh, Singapore- Singha is king, Myanmar-Misspelt Brahma, VarunayaVijaya \& Far East, the Concept of Indosphere, Indosphere versus Sinosphere, Locating India's Soft Power, India Soft Power Challenges, India Soft Power Mechanism, Clash of Civikization: India vs Sinic, Clash of Civilisation: Indic vs Sinic II.

\section{The Outline of the Book}

There are certain issues that need to be addressed in this book review particularly on certain topics related to the relationship between the social, cultural, economic and political terms of India and China as follows. Firstly: Indosphere versus Sinosphere. The author defines the concept of Indosphere which can simply be understood as the sphere of influence of India (p. 97). The India and the Southeast Asian Nations (ASEAN) relationship has been developing for the better during last 25 years. In terms of economic cooperation which was the starting point way back in 1992, the strategic ties between India and ASEAN countries, namely Vietnam, Indonesia, and Singapore, has developed well. On the other hand, ASEAN maritime and border disputes with China in the South China Sea and also the China's hegemonic actions, seem to be pushing the countries towards forging closer ties with India, as the rightful as a dependable counterweight against China.

It is important to note that competition for supremacy between the two great civilizations of India and China, pertaining to territorial expansion of their sphere of influences, has been perceived to be as old as those civilizations. An American Sinologist and Historian, Edwin O. Reischauer has also grouped China, Korea, and Japan into a cultural sphere as the Sinic world, a group of centralized states that share a Confucian ethical philosophy.

Secondly: Locating India's Soft Power, the author argues that the Indosphere is not a construct of an academic imagination, but based on real feelings and collective memories of the people of the constituent countries towards the mother country of India, where the mother country never colonized the countries in Southeast Asia.

Thirdly: India Soft Power Challenges. In this part, the author recognizes the importance of the formal education where India realizes its north-eastern parts are the gateway to the South East Asia region under its Act East policy framework. That reality assumes high importance. 
Fourth: India Soft Power Mechanism. India like many other countries, has its diplomatic corps, to handle India's international relations by engaging with foreign government officials while staying within the policy framework as determined by the Government of India. Abroad as representatives of the Indian state, diplomats perform a number of enabling tasks that help image-building of the state and promote brand India (p. 164).

Fifth: Clash of Civilization: India vs Sinic. India has successfully built a regional power. The author says that as a rival power, India does not sit well in China's scheme of things, which is obvious from its consistently hostile stance against India. He adds that it would be interesting to note that there is a fairly long history of power play between the two great civilizations of Asia and the world viz a vie India and China or the Indic and the Sinic. A long history of kings and kingdoms from South East Asia region having sent their embassies and paid tributes to China which has fed and nourished its sense of a supreme power.

\section{The Significance of the Book}

Understanding these topics is very significant since as it is already known within the dynamics of global trends, that the world is at the edge of a conflict that may end up as severe as those of the $2 \mathrm{O}^{\text {th }}$ century. Understanding the roots of the tension and turmoil that is leading to such an eruption is vital to make the people in the world betterable to understand the existential nature of a conflict that has already been unfolding and which will gain in intensity.

This can be understood through the certain lack of literature and references on the topic. It can be understood that students know the two regions have influenced the dynamics of the Southeast Asian regions, but to what extend have the Indian and Chinese cultures influenced of the regions in Southeast Asia? As mentioned by Professor Madhav Das Nalapat Vice-Chairperson, Manipal Advanced Research Group Manipal Academy of Higher Education, India that Pullind Samant's work on the Indosphere shows the opportunity cost to nations across the decades of not being involved with policy formulation on this issue. He argues that just as Sanatan Dharma embraces all faiths in its universality of application and relevance, so does the Indic civilization encompass the entire globe in its cultural ethos and sweep. He concludes that we are all the cultural offspring of the wells of Indic tradition and thought and also there are no outsiders or strangers in Indic thought. According to Madhav Das Nalapat he says that in Set Theory there are interlocking areas and the Indic has areas of interlocking with other cultures, including the Anglosphere. Therefore, India is at the heart of the $21^{\text {st }}$ century Anglosphere, where it is in "the blood of the mind", that is used to define inclusion. India is at the heart of Mayan civilization, as with the Ashanti in Africa. India is with the peoples of Indonesia and Malaysia and is present in the cultural DNA of East Asia.

He adds that this book can be a significant book for understanding the Southeast Asia region. Therefore, the book really deals not only with the countries of Southeast Asia, but also the Indic strand of civilization as broadly defined. It may also be found in South and North America as well, as in Europe, China, South Korea and in the continent of Africa, which will rise in the $21^{\text {st }}$ century in the manner that Asia did in the $20^{\text {th }}$ century.

It can be understood that whether it be in Indonesia, in Cambodia, or Laos, there is a link with a civilization that ranks together with the oldest in human history and the thread 
(of which has remained unbroken despite occupation and conflicts) is becoming known and celebrated. In addition to this he says also that everybody knows where the Covid 19 virus came from, everybody knows from where the flights departed in the early months of 2020 to spread the novel coronavirus pandemic across the globe, bringing with it disruption dislocation and misery on a scale not seen since the conflict of 1939-1945.

That was different compared to the Chinese influences in the region, where the Chinese influences were not so strong in terms of politics if compared to the Indian influences. Why did this happen in the context of human and cultural dynamics in the archipelago? As already mentioned by Samant the clash between Indic and Sinic, is indeed a clash which is likely to intensify in severity in terms of noble civilization that has been created and propagated by the Chinese Communist Party (CCP) to create a favorable climate within the Peoples Republic of China for its activities at home and abroad. It is said that "New Sinic" is in many particulars different from the original. It is also said that Sinic civilization is undiluted by the Indic, including several of the traditions introduced by Hindu and Buddhist monks into China.

\section{Prospect for Further India, China and Southeast Asian Studies}

There are certain issues related to the impacts of both influences in terms of social culture, economic and political influences in the region, though India and China never colonized the region. The Vietnamese, for instance, that had been influenced for more than thousand years seem never colonized in terms of politics by China, yet Chinese cultural influences have strongly impacted Vietnamese culture. In addition to this, the Balinese in Indonesia, though influenced by the Indic cultural, they never felt politically colonized by Indian or Hindu influences. The Indic or Hindu cultural influences have strengthened the local cultural identities of the Balinese, and indeed the Indic or Hindu influences can be seen in modern Balinese culture until the present time.

Pulind Samant's book on Indosphere Revival: Strategies to meet Sinic Challenge gives a great contribution in order to be able to understand the existence of the Southeast Asia region. Both the Indosphere and the Sinosphere play a major role and they impact the region of Southeast Asia in general, and in Indonesia in particular. Pullind Sammant says that historically, the region's indigenous communities embraced Indic civilization, instead of the Sinic influence. This contact stood suspended when India struggled against western invasions, disrupting the cultural supply chain eastward. In addition to this, India must revive these civilizational bonds, bearing in mind the inevitable clash of civilizations-Indic versus Sinic. Therefore, he argues that framework for wielding and leveraging the soft power capital, a challenge in itself, will have to be highly nuanced and will pay a crucial geostrategic role in the future particularly on this eastern flank of the IndoPacific.

Pulind Samant's book will give a comprehensive and comparative point of view about the Indian and Chinese influences in Southeast Asia. In general, it can be said that the Samant's work is a critical analysis and also gives a great contribution to Southeast Asianists who are paying attention to the area studies not only about India, China, but also to Southeast Asian Studies. In Southeast Asia for instance, not many scholars understand that the Indian or Indic influences are strong in Singapore if compared to the Chinese influences. Samant 
notes that Singapore, called Singapura in Malay language, the speakers of which were the original inhabitants of Singapore before the influx of the Chinese migrants, which originally was Sanskrit Simhapura or Singapura, meaning lion's city must have been named so without any history of being lions' habitat, only because of the then prevalent practice in the Southeast Asia region, of using Indic symbols for the purpose. He adds that since the state was founded by a descendant of Hindu-Buddhist royal lineage, it was appropriate for him to choose an icon of the lion. This argument is useful to our understanding that not only Singapore, but also other Southeast Asia regions that comprise of 11 modern states. South East Asia as one social unit, has both Indian and Chinese cultural influences which can be seen until present day Southeast Asia development.

To sum up, it can be said that this book is very significant and important to be read not only by the academicians in the universities such as social and humanities studies experts, political scientists, historians, archeologists, anthropologists, faith and religious studies experts, students, but also in the context of broader sense for instance diplomats, agencies, bureaucrats and also for the people who involved in the context of non-government organization. This book provides a better understanding of the extend of the influences of India and China in Indonesia in particular, and in all regions of Southeast Asia in general. It is a further contribution in the context of analytical and comprehensive studies, within regional and international studies development.

\section{References}

Samant, P. (2020) Indosphere Revival: Strategies to meet Sinic Challenge. Forum for Integrated National Security 